\title{
Analysis of factors from the external environment in changing business processes
}

\author{
Mihaela Ghicajanu ${ }^{1, *}$ \\ ${ }^{1}$ University of Petrosani, Faculty of Minning, Petrosani, Romania
}

\begin{abstract}
This paper presents and analyzes the factors in the external business environment that determine the need for redesign processes in enterprises or at the business level. At the same time, the influence of the most relevant factors in the external environment will be analyzed in this context based on a case study conducted at the level of the Jiu Valley enterprises. At the same time, the influence of the most relevant factors in the external environment will be analyzed in this context based on a case study conducted at the level of the Jiu Valley enterprises. The research methodology is the questionnaire. The study is broader, but only a part of the research findings, those related to the factors in the external business environment that determine the need for chance or redesign processes in enterprises, are presented this paper. The overall conclusion of the study is that: the need to undertake processes of change or redesign of business is determined in particular by certain factors such as those in the near environment (customers, competition, etc., with intensities close to influence), but also by the changes in the business environment in which the company operates. The results of the study can generally be argued that the company / business and business it is doing is in close connectivity and interdependence with its external environment.
\end{abstract}

\section{Arguments in favor of change and redesign}

The need for change and redesign a business within a company was best argued by Michael Hammer and James Champy in their book in 1993 "Reengineering the Corporation: A Manifesto for Business Revolution." They launched and defined the concept of "business reengineering - redesigning the business" for the first time in an extremist approach. This paper has received many appraisals from: big American companies, business magazines and publications, management teachers, including Peter Drucker. Drucker said this paper "describes the content, motives and methods of a business redesign activity", [5].

Subsequently, other views related to the changes and renewals of management processes that did not see such radical changes appearing. For example, Thomas Davenport believed that redesigning management processes can be accomplished by assimilating the latest technology, which in turn implicitly causes complex changes in work processes, at organizational levels and in human resources, [2]. Al-Mashari and Zairi think that redesigning business processes involve changes in people, behavior and culture first, and

*Corresponding author: ghicajanumihaela@yahoo.com 
then changes in process and technology, [4]. Popa Ion believes that redesign is the ability of an enterprise to adapt to new situations, to assimilate the new things in all structures and systems of the organization, the new things generated by change, [3].

In the paper Internet Business Management [1], it is mentionet that the authors Michael Hammer and James Champy in Re-engineering the Corporation speak of "a theory of radical redesign of business processes, organization, and mentality of an enterprise in order to thrive in the future". In this sense, reengineering aims at a qualitative leap through performance, multiplying efficiency in market conditions, efficiency that can be achieved through processes and structures entirely new. At that time, this is what the two American specialists Hammer and Champy found:

1. that the principles of Adam Smith's classic management after which the firms were organized for two centuries are no longer valid today. In the sense that the principles of organizing enterprises after the division and specialization of labor are no longer in line with the present times;

2. that a new order, a new form of business organization and leadership is required, a major, radical change. This new order in organizing and conducting business is determined by three external factors of influence: Customers, Competition and Change of the Business itself. These external factors have been analyzed in my research on Jiu Valley businesses and how managers of these businesses perceive the need for change as a result of external influences.

\section{The necessity to know about the factors of the business environment in the redesign process}

The analysis of the external environment and the interdependence between it and the enterprise is one of the essential premises in understanding the factors in the external environment, the direct or indirect influences it has on the activity of the enterprise. The evolution of the modern enterprise is now marked by the amplification of its interdependencies with its business environment.

The necessity to know about business factors in the managerial redesign process can be argued in a general way by the fact that the enterprise and the business it carries out is in close connectivity and interdependence with its environment.

The concept of the company's external environment was and is still widely debated in the foreign and Romanian specialized literature in economics and management. Overall, through the external environment or the business environment, we understand "the whole set of heterogeneous conditions that exert influence on the way the company realizes its own goals. It can also be defined as a network of exogenous variables to which the enterprise opposes its own endogenous variables ", [2] (material, human and financial resources).

In the past, for a long time the activity of economic agents has been studied only in terms of production capacities and profit, and the analysis of the global or competitive environment were either ignored or summed up to simplistic analyzes of the market share type business or other static situations. The theorists and practitioners of strategic management and management have understood that the company functions as an open and dynamic system of the global system, being sensitive to the influences of its environment and which in turn influences it to a lesser or greater extent. The magnitude of the company's environmental impact is determined by various characteristics, in particular: the size of the enterprise; market share; the nature of its activity; the type of market it is evolving in; the competitiveness of the sector, etc., [3]. The environment also has the power to influence the activity of an enterprise, and the degree of influence is determined by the sensitivity of the environment, its uniqueness and the dynamics of the environmental elements. 


\subsection{The conditions of research of the factors in the external environment}

\subsubsection{General considerations}

Starting from these considerations, listed in the previous paragraphs, I conducted a research through which I wanted to analyze several aspects related to the Jiu Valley business environment. These were mainly:

- the analysis of the current situation of the Jiu Valley enterprises in terms of the number of active enterprises, their structure according to the criteria of the SMEs, the fields of activity;

- the managers' attitude towards change processes in the external environment and the way they perceive the need to change management processes within the enterprise

- interest and understanding from managers of the implications of change processes or managerial redesign of business

- identifying factors from the external environment with the most influence in determining the need for change in the business processes of the company

- identifying the factors in the internal environment with the greatest influence in determining the need for change at the level of business processes in the company

The research was mainly aimed at analyzing the processes of remodeling and redesigning the business among the enterprises in the Jiu Valley. The study looked at whether they were aware of how to apply such business remodeling processes and aimed at achieving more goals, including the knowledge of the external environment factors presented in this paper. The analysis of the state of the internal conditions in enterprises and the situation of the redesign processes (where such processes were carried out were analyzed all aspects regarding: the stage of realization, the amplitude of the redesigning processes, the targeted processes, the success stories, the objectives of the redesign, , etc.) were presented in other papers.

\subsubsection{The business environmental situation in the Jiu Valley}

In order to have a general idea of the business environment in Jiu Valley and to support the case study I will present very briefly the situation of the environment and of the enterprises from the Jiu Valley.

The Jiu Valley is located in Hunedoara County, Romania and has a surface of 1,281 $\mathrm{km} 2$ and a population of approximately 142,190 inhabitants (2014). The group of towns and localities of the Petroşani Depression is named Jiu Valley because they are crossed by the West Jiu and the East Jiu and is composed of three municipalities: (in order of the population number) Petroşani (44.191), Vulcan (29.535), Lupeni (27,855), and three cities: Petrila (25,650), Uricani $(10,056)$, Aninoasa $(4,906)$. It is currently estimated that more than $40 \%$ of the registered population is abroad for work or in other cities in the country.

Jiu Valley is well known in Romania by the fact that until 1990 (during the communist period) it was a mono-industrial mining region with the largest mining basin where more than 55,000 people worked in about 14 mines spread across the Valley towns, being the largest coal producer in the country. At that time the area was prosperous, and the employees had higher salaries than the country average. At present there are only 2 mining units with only about 3,500 employees in the organization called Hunedoara Energy Complex. Even so the Hunedoara Energy Complex remains the largest employer in the Jiu Valley.

The mono-industrial character of the area, the changes in the national and regional economy over the last 25 years have had negative influences on the Jiu Valley, because it has been more difficult to adapt to these changes, more difficult to create businesses and 
jobs in fields of activity other than the mining industry, which has been predominant for many years and after 1990 .

Although the mining operations have been the economic and social engine of the Jiu Valley, in the last 15 years, businesses and other fields of activity such as bakery, trade, tourism, transport, finance, banks, insurance, car services, etc. have developed. The data presented are from 3-4 years ago, but the current situation is not much changed anyway. In the year 2014, approximately 1700 businesses operated in the Jiu Valley, most of which were micro-enterprises with up to 9 employees (over 95\%) and small enterprises with a maximum of 50 employees, and they received / earned the minimum wage in the economy. The depopulation of the Jiu Valley and especially of the young people has been recorded in recent years. They look for better paid jobs, where they can study, where they can develop professionally and for a better living.

The general situation in the Jiu Valley (personal appraisal as a resident) is not favorable either for the quality of life nor for professional development and without an optimistic future, if internal analyzes are not made at the level of the business environment and at the level of the enterprises. These analyzes are needed to see what solutions are and how to revitalize the area from an economic, social and cultural point of view.

This is the context in which I have researched the most representative businesses in the Jiu Valley that have an impact on the business environment in the area, to see what kind of attitude the managers have towards changing and redesigning business, and how they perceive the business environment in the area.

\subsection{Methodology and research hypotheses}

The research was carried out through the questionnaire method and direct interview with the managers of the Jiu Valley activities. The questionnaire contains 24 questions, each containing multiple sets of appreciation and various scales of values, of which $20 \%$ of the questions concern the objective of this research. The representative sample consisted of 34 enterprises from different fields of activity, and the response rate was $64 \%$.

The hypotheses of the research presented in this paper were as follows:

Hypothesis 1: The need for planning and starting a business change program and how it is driven within an enterprise is determined by business forces (customers, the market, competition).

Hypothesis 2: The need to think and start a business change program and how it is driven within an enterprise is determined by the weaknesses within it (differentiated by the management system components).

Hypothesis 3: In order to achieve increased enterprise performance, other strategic options can be chosen to streamline business processes such as moderate change or continuous improvement.

\subsection{Research results}

\subsubsection{The influence of factors on the necessity for change}

The research results confirm that the respondents believe that the decision to start a process of change within the enterprise, aiming at streamlining and optimizing the business processes, is determined by the external factors: clients, competition, the business environment in general, but also by the influences of the internal factors. The perception of the intensity of these internal and external forces is presented below: 
- the external forces have a higher intensity than the internal forces of influence, where 1 has low influence value, 5 - very strong influence.

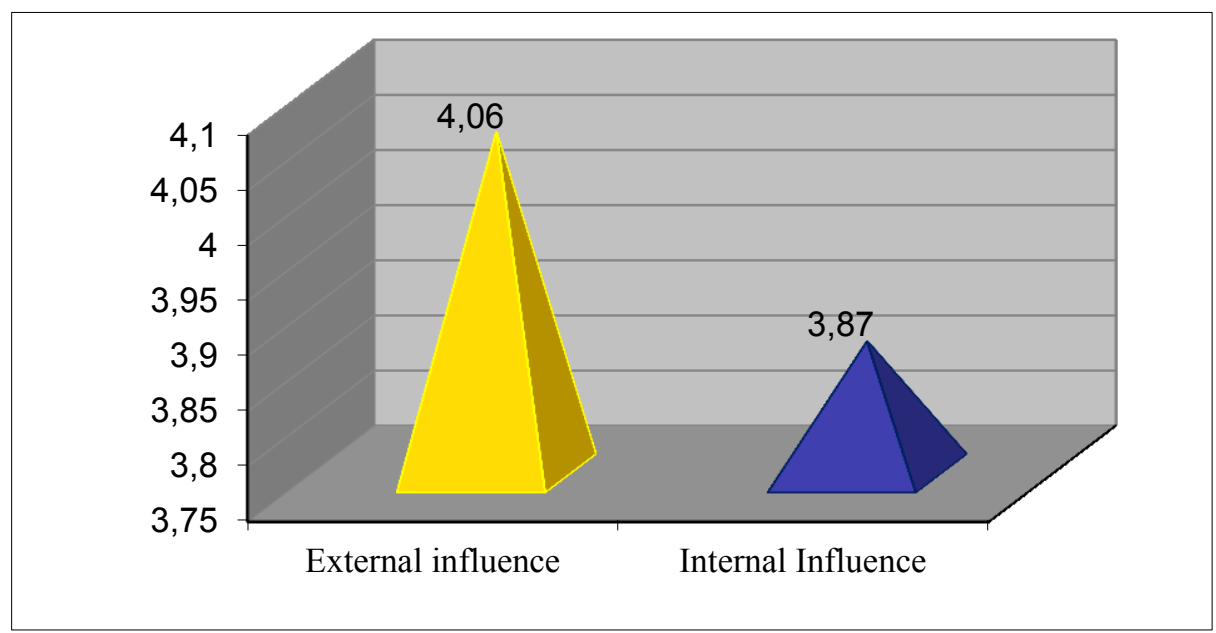

Fig.1. Assess the influence of external and internal factors on the need to implement change processes - also by categories of external factors managers consider that: customers, overall changes in the business environment, the market, generally have higher intensity (other than direct or indirect competition); and the weakest influence is indirect competition.

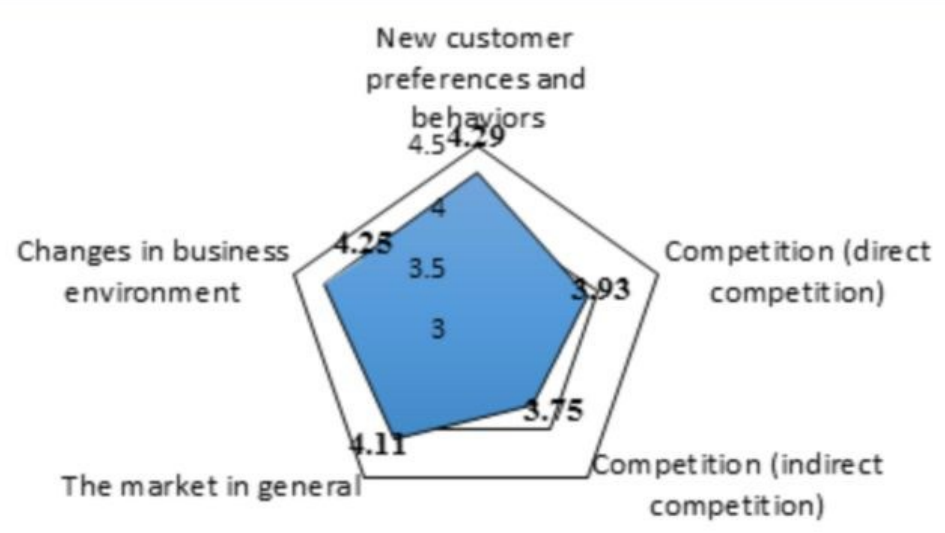

Fig.2. The intensity of external factors in the need to implement change processes

- among the internal forces, the most influential is the deficiencies and the lack of managerial methods and techniques and the communication, and the lowest influence is appreciated by the IT deficiencies. 


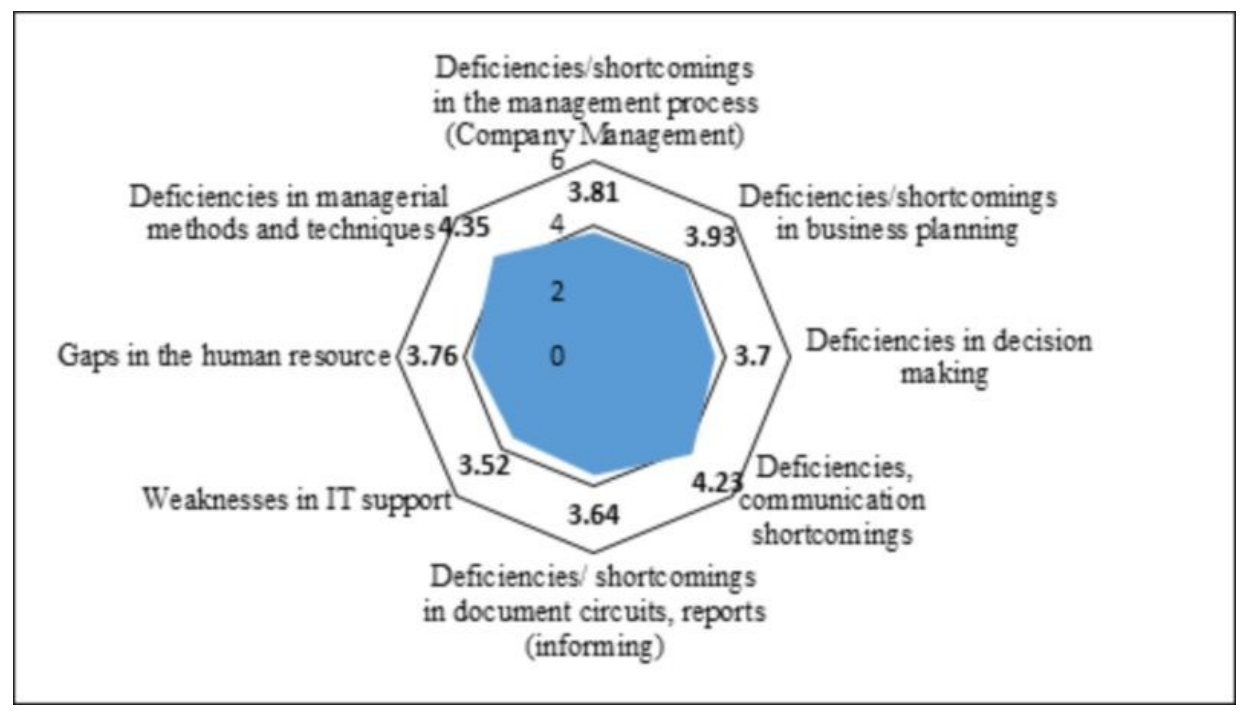

Fig.3. Intensity of internal factors in the need to implement change processes

\subsubsection{Attitude towards redesign: interest, orientation, options}

In detail, the results related to the state of affairs in the enterprises in Jiu Valley are as follows:

- The interest and the orientation of management are preponderant to the improvement of the already existing processes in $45 \%$ of the cases. There is no business process approach and no project management system is applied to any surveyed enterprise.

\section{Em phasis on organizational definition of a process / process architecture architecture \\ Em phasis on com pany-wide redesign processes}

\section{Em phasis on improving existing processes \\ Em phasis on automation of departmental processes / organization level \\ Emphasis on improving specific processes at the department level}

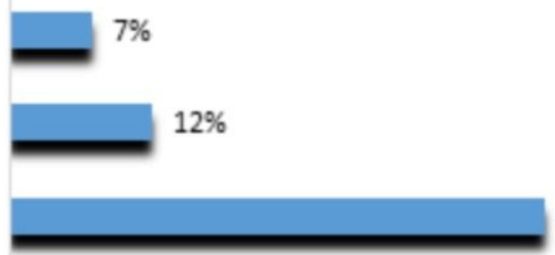

Fig.4. Interest and business orientation

- If we were to cumulate the first three options that are generically characterized to improve processes, department actions, or to automate them, the cumulative percentage is about $80 \%$.

- With regard to recent business initiatives, management has predominantly taken actions towards measuring and monitoring performance across the organization and tried minor changes, $27-29 \%$, followed by automation and IT development and in the least amount they tried radical changes $5 \%$. 


\section{Developing a Process Architecture at an organization level (modern IT)
Measuring and monitoring perform ance across the organization \\ Automating processes using integrated software solutions (IT and modern... Im proving the efficiency of existing processes (minor changes) \\ Developing a Perform ance Measurem ent System for Processes of the Organization}

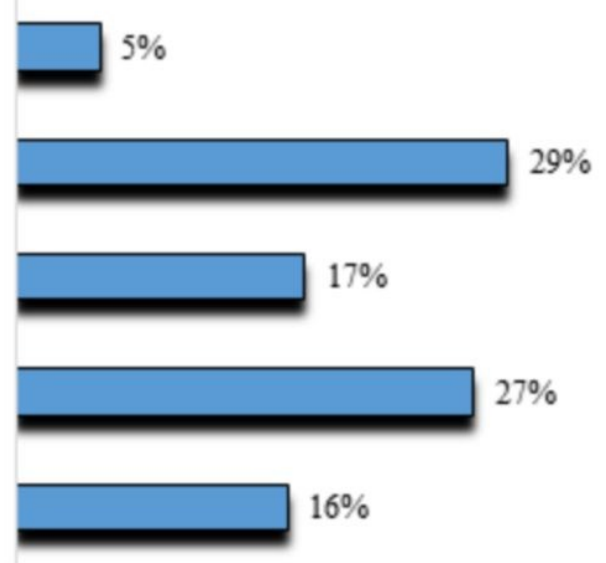

Fig.5. Initiatives in business management

- the magnitude of the current change in the enterprises in the five categories of listed changes is limited to three dimensions: an improvement in 55\% of enterprises, a moderate change to $36 \%$ of them and only $9 \%$ have changed processes. Moderate redesign and radical change have not been applied by any enterprise in the representative sample.

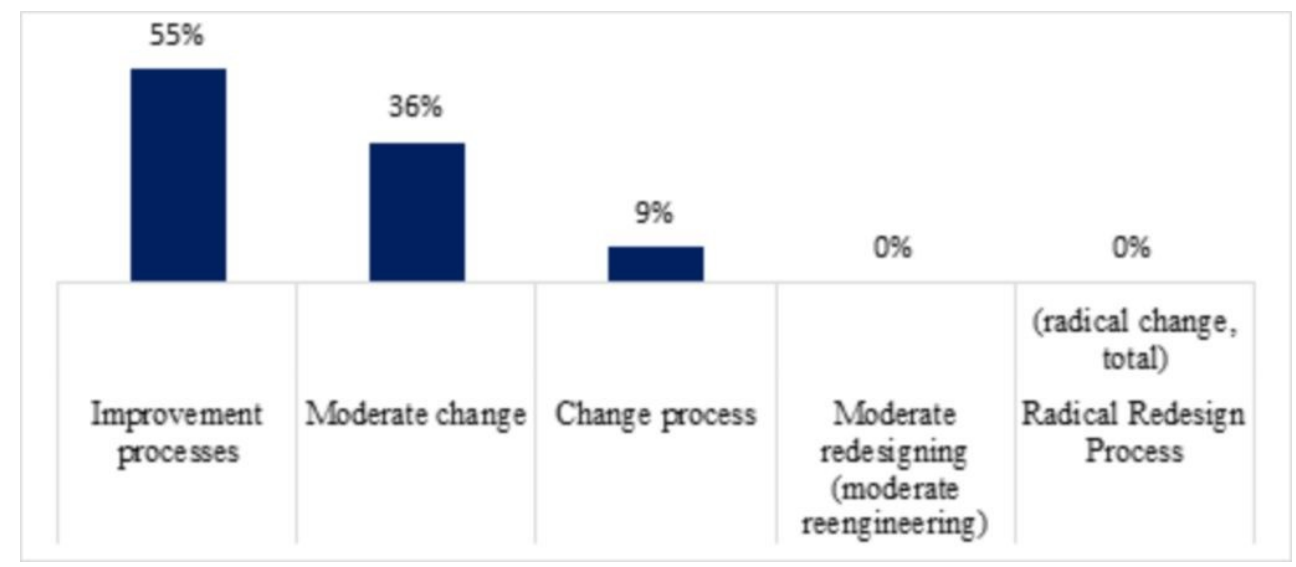

Fig.6. The magnitude of change in enterprises in the Jiu Valley

\section{Conclusions}

The general conclusions that can be drawn from the analysis of the answers given by the managers of the most representative enterprises in Jiu Valley are:

- managers' actions and decisions are more focused on the inside of the enterprise and less towards outside, towards the market

- although it is known that there is competition on the market and the client is a priority, the actions of the majority of managers deal superficially with these issues

- the attitude towards redesigning the business is of low interest, and those who apply or have applied make moderate changes, and the success rate in finalizing and reaching their goals is quite low 
- many do not know what managerial redesign processes involve, they do not understand business processes as a whole, and some think that redesign represents the endowment with modern technology, IT or automation

- most of them do not have a strategic vision and planning, they are predominantly focused on current actions

- female managers are more receptive and open to radical changes

- goal ranking is customer-driven, cost-effective and quality-driven

- more and more managers perceive the fact that they need to take into account the requirements and exigencies of the clients, fact that is not fully accepted yet

In conclusion, the interest and orientation of the management of the Jiu Valley enterprises are preponderant to the improvement of the already existing activities and processes. Overall, there is an openness to change, but most opt for continuous improvement, and only a small part (about $9 \%$ of mangers) would opt for change process.

\section{References}

1. D. Oprean, V. Oprean, D.M Racoviţan, L Rusu, Managementul afacerilor pe Internet, (Editura Tehnica București, 2007)

2. D. S. Olaru, Economia şi gestiunea întreprinderii, (Ed. Tribuna Economică, Bucureşti, 1999)

3. I. Popa, Management general, available at http://www.bibliotecadigitala.ase.ro/biblioteca/biblioteca1.asp?id=7, (ASE Bucureşti, 2015)

4. M. Al-Mashari,, M. Zairi, BPMJ, 6/1, 10-42 (2000)

5. M. Ghicajanu, PhD Thesis: Managerial Redesign in Business with study on companies in the Jiu Valley, University Valahia of Targoviste, (2015)

6. M. Ghicajanu, Reproiectarea managerială a afacerilor, (Editura Universitas, Petrosani, 2018)

7. M. Ghicajanu, 6th International Management Conference:" Performance management or Management Performance?", 306-314, (2018)

8. M. Hammer, J. Champy, Reengineering-ul (reproiectarea) intreprinderii: un manifest pentru o revoluţie în managementul afacerilor, (Editura Tehnică București, 1996)

9. Statistici INSSE (2016) 